\title{
Aggressive management of an epidemic of chronic pseudophakic endophthalmitis: results and literature
} survey

\author{
N K Rogers, P D Fox, B A Noble, K Kerr, T Inglis
}

\begin{abstract}
Six cases of chronic endophthalmitis following extracapsular cataract extraction and lens implantation are reviewed. All were referred for tertiary management by one surgeon over a period of just over 2 years. In two of the cases coagulase negative staphylococci were isolated and in three Propionibacterium spp were retrieved. In the remaining case a mixed growth of coagulase negative staphylococci and Propionibacterium acnes was cultured. The surgical management, microbiological results, and eventual visual outcome are discussed. To our knowledge, this is the first documented outbreak of chronic pseudophakic endophthalmitis with commensal organisms from a single centre.

(Brf Ophthalmol 1994; 78: 115-119)
\end{abstract}

Department of

Ophthalmology, The Clarendon Wing, The General Infirmary at

Leeds, Leeds

N K Rogers

P D Fox

B A Noble

Department of

Microbiology, The

University of Leeds,

Leeds

K Kerr

T Inglis

Correspondence to:

Mr B A Noble, Department of Ophthalmology, The

Ophthalmology, The Clarendon Wing, The Gener Infirmary at Leeds, Belm Grove, Leeds LS2 9NS.

Accepted for publication 17 August 1993
Chronic endophthalmitis is a rare complication of cataract surgery but has been well documented in several small series. ${ }^{1-10}$ The clinical picture is of a recurrent, often low grade, uveitis which partially responds to topical or systemic steroids. It may occur months or even years after the initial surgical event and presents with mild pain, granulomatous uveitis with or without hypopyon, vitreous activity, capsular thickening, or plaque and, in the later stages, visual loss (Fig 1). The records of six patients referred to us have been reviewed retrospectively. Five underwent anterior chamber lavage, removal of intraocular lens, capsulectomy, and anterior vitrectomy with injection of intracameral antibiotics. One patient, with an already detached retina, had a pars plana vitrectomy and injection of intravitreal antibiotics. In each case incuba-

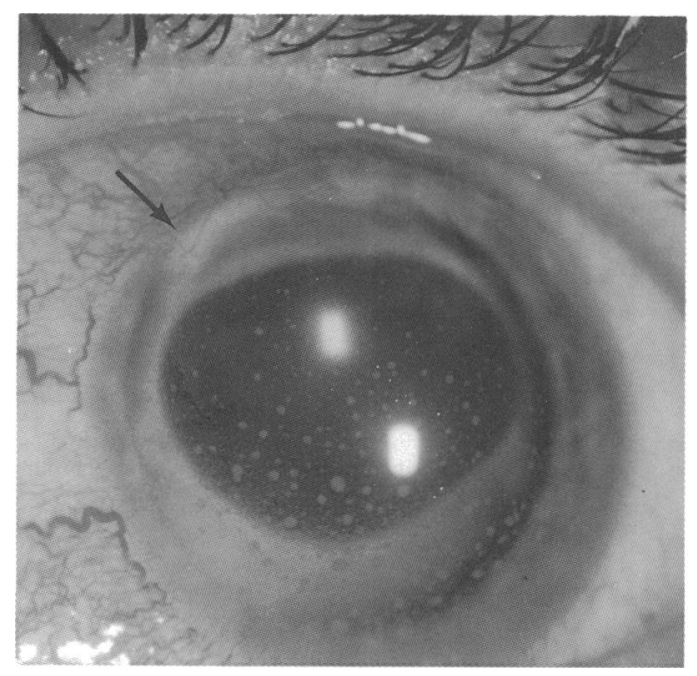

tion yielded positive culture, in some cases after a prolonged period. Four of the cases had a good visual outcome (that is, $6 / 18$ or better), one has persistent macular oedema, and one has an intractable retinal detachment. Four of these patients have had raised intraocular pressure following diagnostic/therapeutic surgery. No cases were excluded because of failures of diagnosis or treatment.

\section{Patients and methods}

\section{CASE 1}

A 61-year-old man underwent routine uncomplicated left extracapsular cataract extraction and lens implant (19 February 1990). Two weeks after the operation he was noted to still have considerable anterior chamber activity but this responded to topical steroids. Seven months after the operation he reported deterioration in vision (from 6/9 to perception of light) and tertiary referral was made to elucidate the cause of his severe uveitis. The diagnoses were endophthalmitis and retinal detachment. A coagulase negative Staphylococcus was retrieved from a pars plana vitrectomy sample.

\section{CASE 2}

An 80-year-old man underwent right extracapsular cataract extraction with sphincterotomy and lens implant (27 March 1991). He had a prolonged recurrent postoperative uveitis that partially responded to topical steroids. Five months after his initial surgery and having had three episodes of hypopyon uveitis, his vision deteriorated from $6 / 12$ to hand movements and he was referred for further management. A coagulase negative Staphylococcus was cultured from the aqueous, lens, capsular bag, and vitreous samples. Eight months after diagnostic and therapeutic surgery a posterior chamber sutured lens was implanted. Uncontrolled glaucoma was surgically treated with a 5-fluorouracil enhanced trabeculectomy and current best corrected vision is $6 / 18$.

\section{CASE 3}

A 50-year-old man with retinitis pigmentosa underwent uncomplicated left extracapsular cataract extraction and lens implant (11 March 1991). Two months postoperatively he presented with uveitis and hypopyon and marked decrease in visual acuity (from 6/12 to hand movements). Right cataract surgery was performed uneventfully 4 months after the left. Tertiary referral was

Figure 1 Anterior chamber showing granulomatous

keratic precipitates, capsula superiorly indicated by the
} 
made 7 months after the first operation with left uveitis not controlled by steroids. A coagulase negative Staphylococcus was isolated from the aqueous, viridans group streptococci from the lens, and Propionibacterium acnes from the capsule. No organisms were found in the vitreous sample. Fifteen months later a posterior chamber sutured lens was inserted and current best corrected acuity is $6 / 9$.

CASE 4

A 74-year-old myopic woman underwent bilateral simultaneous extracapsular cataract extractions with lens implants (October 1990). Three months after surgery she presented with a left uveitis partially responding to topical steroids and antibiotics (gentamicin and a cephalosporin). YAG capsulotomy was performed (August 1991) and this provoked further uveitis and deterioration of vision to counting fingers. She was referred for investigation and treatment and underwent left vitrectomy 1 year after her initial surgery. Propionibacterium acnes was isolated from the lens, capsule, and vitreous, but the aqueous was sterile. Given her axial myopia, secondary lens implantation has been unnecessary and best corrected acuity is $6 / 12$. Secondary glaucoma is satisfactorily controlled with topical $\beta$ blockers.

CASE 5

An 84-year-old man underwent right extracapsular cataract surgery with lens implant (24 September 1991). Three months later he presented having sustained minor trauma to the eye with a uveitis that remitted and relapsed with topical steroids. His visual acuity fell from $6 / 6$ to hand movements. He was referred for further investigation 2 months after his initial surgery. Propionibacterium acnes was isolated from the aqueous, but all other samples were sterile. He has had prolonged cystoid macular oedema and secondary glaucoma. Current best corrected acuity is $6 / 24$ and he is awaiting secondary lens implantation.

CASE 6

An 82-year-old man underwent bilateral extracapsular cataract surgery (left eye 1988; right eye 19 March 1990) with lens implants. The right eye had several episodes of uveitis responsive in part to steroids, but as soon as topical therapy was discontinued the uveitis flared up. He was referred for vitrectomy 27 months after initial surgery, when his visual acuity had deteriorated to $6 / 18$ from a best postoperative acuity of $6 / 5$. Propionibacterium granulosum was retrieved from the lens, capsule, and vitreous, but the aqueous was sterile. Eight months later a posterior chamber sutured intraocular lens was implanted and his current best corrected acuity is $6 / 6$.

\section{LABORATORY METHODS}

In all but the first case, the anterior chamber contents were aspirated, an infusion cannula inserted, the original corneal cataract section partially reopened, and the intraocular lens removed. The capsule was then gently teased from its zonules and removed intact or piecemeal. An ocutome anterior vitrectomy was performed initially without infusion so as not to dilute the microbiological sample. Then, as much organised vitreous as possible was removed. Intracameral antibiotics were administered and topical and systemic antibiotics were also instigated (Table 1). A microbiologist was present in theatre to handle the samples as they were taken. Each specimen was inoculated on to horse blood agar, chocolate agar, Sabouraud's agar, thioglycolate enrichment broth, and glucose serum broth. An immediate Gram stain was also performed. Samples were incubated under the appropriate atmospheric conditions. Organisms isolated were identified by standard biochemical methods.

\section{Results}

The microbiological results are summarised in Tables 2 and 3. Positive cultures were obtained in all six cases, but no single site was uniformly productive on culture. The aqueous was sterile in two cases, the vitreous in two, the lens in one, and the capsule in one. Initial Gram stain was positive in five out of the six cases. The time to culture varied between 2 and 12 days. In case No 5, the Gram stain was positive for all four specimens, especially on the lens and the capsule, but organisms were grown only from the aqueous and not until after 7 days. This illustrates the fastidious nature of the organisms and the importance of extended incubation. In

Table 1 Summary of antibiotic therapy and details of the age and sex of the patients

\begin{tabular}{|c|c|c|c|c|c|}
\hline \multirow[b]{2}{*}{ Case } & \multirow[b]{2}{*}{ Age/sex/eye } & \multicolumn{4}{|c|}{ Organism and therapy } \\
\hline & & Organism & Intracameral & Topical & Systemic \\
\hline 1 & $61 / \mathrm{M} / \mathrm{L}$ & Staph & $\begin{array}{l}\text { Vancomycin/cephazolin } \\
\text { Methicillin/gentamicin }\end{array}$ & $\begin{array}{l}\text { Methicillin/gentamicin } \\
\text { Prednisolone }\end{array}$ & $\begin{array}{l}\text { Gentamicin/prednisolone } \\
\text { Fusidic acid }\end{array}$ \\
\hline 2 & $80 / \mathrm{M} / \mathrm{R}$ & Staph & Gentamicin & $\begin{array}{l}\text { Gentamicin/cephazolin } \\
\text { Prednisolone }\end{array}$ & $\begin{array}{l}\text { Cephazolin } \\
\text { Flucloxacillin }\end{array}$ \\
\hline 3 & $50 / \mathrm{M} / \mathrm{L}$ & $\begin{array}{l}\text { Staph } \\
\text { Strep } \\
\text { P acnes }\end{array}$ & Vancomycin/gentamicin & $\begin{array}{l}\text { Gentamicin/cefuroxime } \\
\text { Prednisolone }\end{array}$ & $\begin{array}{l}\text { Prenisolone } \\
\text { Vancomysin }\end{array}$ \\
\hline 4 & $74 / F / L$ & $P$ acnes & Vancomycin/gentamicin & $\begin{array}{l}\text { Gentamicin/cephazolin } \\
\text { Prenisolone }\end{array}$ & $\begin{array}{l}\text { Prednisolone } \\
\text { Gentamicin/vancomycin } \\
\text { Cephazolin/penicillin }\end{array}$ \\
\hline 5 & $84 / M / R$ & $P$ acnes & Vancomycin/cefuroxime & $\begin{array}{l}\text { Cefuroxime/vancomycin } \\
\text { Prednisolone }\end{array}$ & $\begin{array}{l}\text { Cefuroxime } \\
\text { Cephradine }\end{array}$ \\
\hline 6 & $82 / \mathrm{M} / \mathrm{R}$ & Pgran & Vancomycin/gentamicin & $\begin{array}{l}\text { Gentamicin/cefuroxime } \\
\text { Vancomycin } \\
\text { Prednisolone }\end{array}$ & $\begin{array}{l}\text { Ciprofloxacin } \\
\text { Rifampicin } \\
\text { Vancomycin }\end{array}$ \\
\hline
\end{tabular}


case No 2, some of the organisms were already phagocytosed, but still intact, which may be another reason for the difficulty in culturing organisms in this condition. Given the unpredictability of which samples yielded positive cultures, we advocate this radical approach.

The visual results are summarised in Table 4. All had initially successful cataract surgery which progressed to severe visual loss at the time of referral. In four cases the best corrected visual acuity after surgical intervention as described above, was better than $6 / 18$, one still has persistent macular oedema and the detached retina was deemed inoperable. Of note here is the recurrent

Table 2 Gram stain results for samples taken from each of the four possible sites

\begin{tabular}{|c|c|c|}
\hline Case & Organism & Gram stain \\
\hline $\begin{array}{l}1 \\
2\end{array}$ & $\begin{array}{l}\text { Staph } \\
\text { Staph }\end{array}$ & $\begin{array}{l}\text { + ve Cocci from vitreous } \\
\text { Pleomorphic + ve cocci found in all four } \\
\text { samples. Some phagocytosed }\end{array}$ \\
\hline 3 & $\begin{array}{l}\text { Staph } \\
\text { Strep } \\
\text { Pacnes }\end{array}$ & $\begin{array}{l}\text { + ve Cocci from intraocular lens, capsule and } \\
\text { vitreous, none from anterior chamber }\end{array}$ \\
\hline $\begin{array}{l}4 \\
5\end{array}$ & $\begin{array}{l}P \text { acnes } \\
P \text { acnes }\end{array}$ & $\begin{array}{l}\text { No organisms seen } \\
\text { All four specimens showed + ve coccobacilli, } \\
\text { especially lens/capsule }\end{array}$ \\
\hline 6 & Pgran & + ve Cocci from vitreous \\
\hline
\end{tabular}

Table 3 Summary of microbiological findings. The time shows the period in days to positive culture and then to sensitivities

\begin{tabular}{|c|c|c|c|c|c|c|}
\hline \multirow[b]{2}{*}{ Case } & \multicolumn{5}{|c|}{ Microbiological sources of growth } & \multirow[b]{2}{*}{ Time } \\
\hline & Organism & Aqueous & Lens & Capsule & Vitreous & \\
\hline 1 & \multirow{5}{*}{$\begin{array}{l}\text { Staph } \\
\text { Staph } \\
\text { Staph } \\
\text { Strep } \\
\text { Pacnes } \\
\text { P acnes } \\
\text { Pacnes } \\
\text { P gran }\end{array}$} & \multicolumn{3}{|c|}{ Not applicable } & + & 3 \\
\hline 2 & & \multirow{2}{*}{$\begin{array}{l}+ \\
+\end{array}$} & + & ++ & + & 2 \\
\hline 3 & & & + & & Nil & $3-12$ \\
\hline 4 & & Nil & + & +++ & + & 5 \\
\hline $\begin{array}{l}5 \\
6\end{array}$ & & $\stackrel{+}{\mathrm{N} i l}$ & $\begin{array}{c}\text { Nil } \\
+\end{array}$ & $\begin{array}{c}\text { Nil } \\
+\end{array}$ & $\begin{array}{c}\text { Nil } \\
+\end{array}$ & $\begin{array}{l}7-10 \\
5\end{array}$ \\
\hline
\end{tabular}

Table 4 Visual outcome indicating the best acuity immediately after cataract surgery (column 1), the acuity before tertiary referral (column 2), and the final acuity after diagnostic and therapeutic surgery and secondary lens implant if appropriate (column 3).

\begin{tabular}{lllll}
\hline & \multicolumn{2}{l}{ Vision } & & \\
\cline { 2 - 4 } Case & Post-ECCE & Referral & Current & Organism \\
\hline 1 & $6 / 9$ & PL & HM & Staph \\
2 & $6 / 12$ & HM & $6 / 18$ & Staph \\
3 & $6 / 12$ & HM & $6 / 9$ & Staph/Strep/P acnes \\
4 & $6 / 6$ & CF & $6 / 12$ & Pacnes \\
5 & $6 / 6$ & HM & $6 / 24$ & Pacnes \\
6 & $6 / 5$ & $6 / 18$ & $6 / 6$ & Pgran \\
\hline
\end{tabular}

ECCE = extracapsular cataract extraction; $\mathrm{PL}=$ perception of light; $\mathrm{HM}=$ hand movements; $\mathrm{CF}=$ counting fingers. Case No 1 had a retinal detachment at presentation. Case No 5 still has persistent macular oedema.

Table 5 Intraocular pressures at presentation and subsequently

\begin{tabular}{lllll}
\hline & \multicolumn{3}{l}{ Intraocular pressure $(\mathrm{mm} \mathrm{Hg})$} & \\
\cline { 2 - 4 } Case & Organism & Referral & Post biopsy & Comment \\
\hline 1 & Staph & 10 & $8-14$ & Retina detached \\
2 & Staph & 40 & $24-50$ & 5-FU, trabeculectomy \\
3 & Staph & & & \\
& Strep & 30 & $30-15$ & Timolol \\
& Pacnes & & & \\
4 & Pacnes & 30 & $30-18$ & Timolol \\
5 & Pacnes & 15 & $16-26$ & (Acetazolamide for CMO) \\
6 & Pgran & 14 & $8-12$ & \\
\hline
\end{tabular}

problem of controlling intraocular pressure both before and after surgery (Table 5). Three of our six patients have required ocular hypotensive agents or surgery and one has pressures at the upper range of normal despite taking acetazolamide for macular oedema. The trabecular meshwork of the patient who underwent trabeculectomy was densely infiltrated with inflammatory cells.

\section{Discussion}

Epidemics of acute pseudophakic endophthalmitis have been reported in the literature. ${ }^{112}$ Pseudomonas spp contaminated intraocular lenses and intraocular fluid infusions have been reported and two cases of staphylococcal endophthalmitis have been linked with indistinguishable isolates from the nose of a surgeon who wore his mask under his nares. An epidemic of chronic pseudophakic endophthalmitis due to Paecilomyces lilacinus contamination of neutralising fluids has also been described. ${ }^{13}$ We know of no other report of a localised outbreak of chronic pseudophakic endophthalmitis from a single referring centre.

Propionibacterium acnes, formerly Corynebacterium paroum ${ }^{14}$ is a variably staining Gram positive pleomorphic anaerobic bacillus (Fig 2), whose natural habitat is the human sebaceous follicle and is a normal commensal of the conjunctival sac. It is associated with chronic skin infections, as its name suggests, and has been found to contaminate a variety of prosthetic devices. ${ }^{15}$ It is a potent stimulant of the immune system, activates complement via the classic and alternative pathways, and produces chemotactic factors, but is largely resistant to the killing mechanisms of polymorphonucleocytes and monocytes, such that after phagocytosis it persists intracellularly. ${ }^{16}$

The clinical course of chronic infective endophthalmitis is similar to that of phakoantigenic uveitis and it has been suggested that there is an adjuvant effect of the bacteria with residual soft lens material to provoke an immune response. ${ }^{417}$ Were this to be the case one might expect that there would be some incidence of associated uveitis of the other eye. However, in a series of 26 cases of culture proved $P$ acnes endophthalmitis there was no evidence of fellow eye involvement ${ }^{10}$ and the cellular profile of the inflammatory exudate is not what would be expected for an anaphylactic picture. ${ }^{9}$

Fox et $a l,{ }^{7}$ in a review of 19 cases of late onset chronic uveitis, report that Gram stain was only positive for one case out of 12 with proved $P$ acnes infection. Cultures may take up to 10 days to show an identifiable growth and this reflects not only its fastidious nature, but also that it may be sequestered within the inflammatory cells or within colonies in the capsular bag. There have been numerous reports of bacterial colonisation of intraocular lenses in both experimental $^{1819}$ and clinical ${ }^{20-24}$ settings, but the uncertainty as to whether or not to remove the lens continues. ${ }^{25}$ Successful treatment of different forms of endophthalmitis has been reported with the prosthesis left in situ, ${ }^{2126-28}$ while others have vigorously supported its removal. ${ }^{2930}$ 


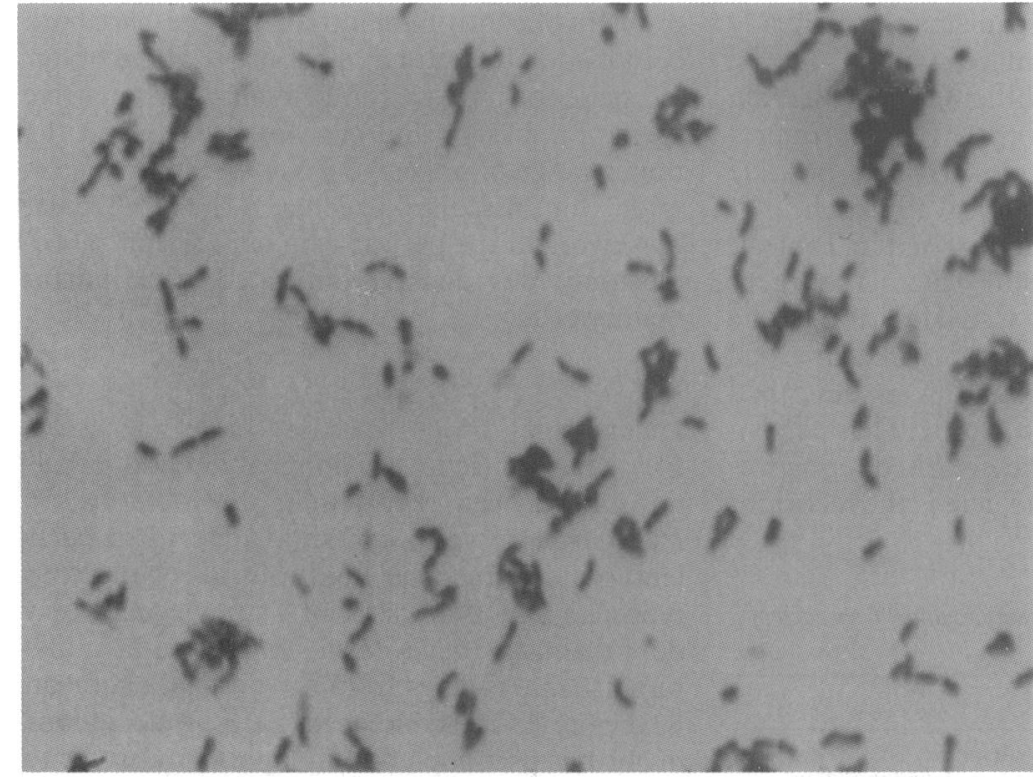

Figure 2 Gram stain of Propionibacterium acnes showing variably staining Gram positive pleomorphic bacilli. When the organisms are fresh out of the eye the cell morphology is less uniform and the staining more variable such that a report of mixed Gram positive and negative rods and cocci is possible. florid category and justify our radical approach.
Zambrano et $a l^{5}$ have suggested that the severity of the condition should dictate the therapeutic strategy. All six of our cases fall into the more We recognise that there is no consensus in the literature on precisely how aggressively to treat this condition, but when it is treated inadequately, the patients enter a spiral of incomplete interventions leading to blindness.

There have been reports of exacerbation of this condition with YAG laser capsulotomy ${ }^{40}$ and this would be consistent with the histological and microbiological findings of localised capsular microabscesses. ${ }^{21}{ }^{24}$ 30-32 However, it should be noted that the presence of a capsule is not absolutely necessary. ${ }^{21}{ }^{33}$ Our results here of the marked capsular colonisation (Fig 3, Tables 2 and 3 ) lead us to favour a more aggressive

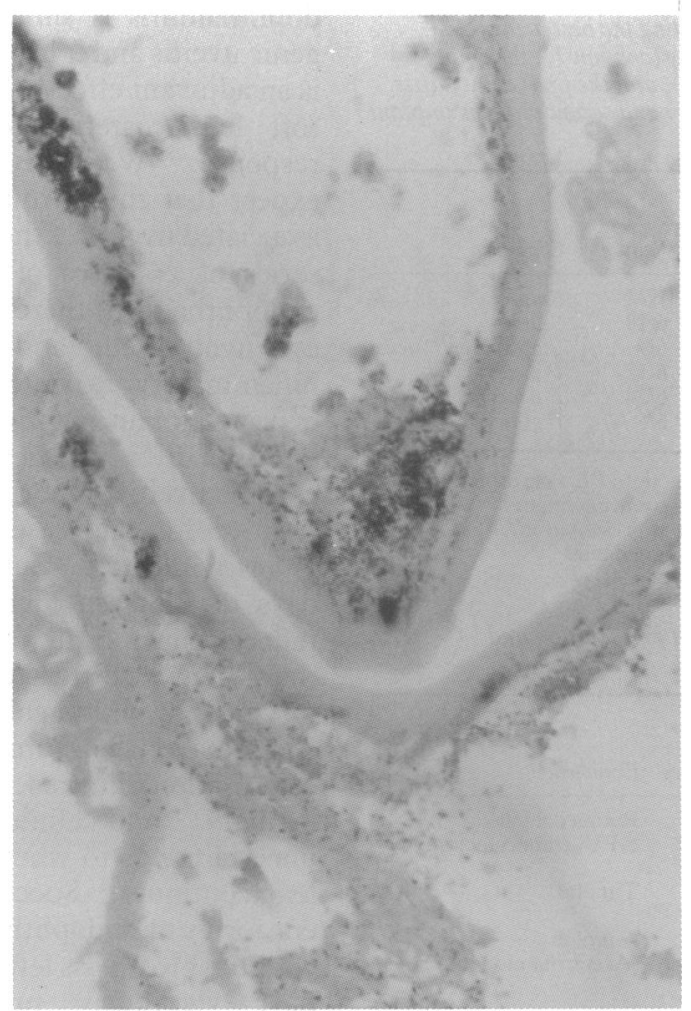

approach which debulks the pathological load and removes the infected prosthesis and tissues, since it has been shown that bacteria adherent to the lens have enhanced protection from concentrations of antibiotic well above the minimum inhibitory concentrations normally required. ${ }^{19}$

Despite the uncertainty over the best way of treating this condition there is remarkable unanimity over the need for committed and enthusiastic microbiological processing of the samples. We have found the presence of a microbiologist in theatre a great asset and reassurance, since there is an exponential loss of colony forming units with time. Samples of the aqueous, capsular plaques, and vitreous were incubated on blood agar, chocolate agar, and Sabouraud's plates. Thioglycollate and glucose serum broth should also be used but any temptation to use blood culture bottles alone should be avoided. ${ }^{34} 35$

The sensitivity of Propionibacterium acnes to standard antibiotics has been documented in vitro $^{36}$ and this has been largely verified by the clinical ophthalmic experience. Our choice of antibiotics in these cases was driven initially by personal preference and subsequently by the microbiological data as they became available. Penicillin and its derivatives, cephalosporins and vancomycin, have good activity but the aminoglycosides have little effect, as one would expect for an anaerobic organism. Intravitreal vancomycin (with or without cephazolin) is the antibiotic of choice in chronic pseudophakic endophthalmitis since vancomycin is effective against the increasingly common methicillin resistant staphylococci ${ }^{37}$ and against streptococci. ${ }^{38}$ Propionibacterium acnes is sensitive to vancomycin, but cephazolin may be more effective. ${ }^{36}$ These intracameral antibiotics may need to be repeated, ${ }^{6}{ }^{39}$ but care should be taken with the possibility of retinal toxicity arising from repeated injections. ${ }^{40}$ The use of systemic and topical antibiotics remains a matter of debate.

\section{Conclusion}

Recent reviews of the incidence of postoperative endophthalmitis indicate a frequency of between 1 and 3 per 1000 , rising to nearly 6 per 1000 if vitreous is lost. ${ }^{41} 42$ The ratio of acute to chronic cases may be between $5: 1$ and $2: 1,{ }^{28} 3840$ indicating that the rate of chronic pseudophakic endophthalmitis should be of the order of 5 per 10000. Given the high incidence of lens and anterior chamber contamination, ${ }^{18} 43$ it is perhaps remarkable that endophthalmitis is not more common after cataract surgery. The unusual features of this series are (i) the single referring centre, (ii) the short time period, and (iii) higher than expected incidence. Possible aetiological factors are being sought, but none has been identified as yet.

This report gives only the second case of Propionibacterium granulosum endophthalmitis of which we are aware ${ }^{44}$ and an unusual case of mixed Staphylococcus/Propionibacterium endophthalmitis which has been reported only twice elsewhere. ${ }^{26} 45$ The finding of raised intraocular pressure as in four of these six cases has
Figure 3 Photomicrograph of the capsule of case No 2 showing multiple colonies of Gram positive cocci within stain, magnification $\times 15$. 
not been noted as a dominant feature in other reports.

Chronic pseudophakic endophthalmitis is likely to be caused by pathogens of low virulence such as Propionibacterium acnes, Staphylococcus epidermidis, and Candida parapsilosis. ${ }^{7}$ We have shown that planned and aggressive surgical management with enthusiastic microbiological support and intravitreal antibiotics hold the key to diagnosis and good visual outcome.

We are grateful for the assistance of Dr S Al-Saraj, Department of Neuropathology, the General Infirmary at Leeds, who provided the histology.

1 Meisler DM, Palestine AG, Vastine DW, Demartini DR Murphy BF, Reinhart WJ, et al. Chronic Propionibacterium endophthalmitis after 'extracapsular cataract extraction and endophthalmitis after 'extracapsular cataract extraction and intraoc

2 Ficker L, Meredith TA, Wilson LA, Kaplan HJ, Kozarsky AM. Chronic bacterial endophthalmitis. Am $\mathcal{f}$ Ophthalmol 1987; 103: 745-8.

3 Roussel TJ, Culbertson WW, Jaffe NS. Chronic postoperative endophthalmitis associated with Propionibacterium acnes. Arch Ophthalmol 1987; 105: 1199-201.

4 Meisler DM, Mandelbaum S. Propionibacterium associated endophthalmitis after extracapsular cataract extraction Review of reported cases. Ophthalmology 1989; 96: 54-61.

5 Zambrano W, Flynn HW, Pflugfelder SC, Roussel TJ Culbertson WW, Holland S, et al. Management options for Propionibacterium acnes endophthalmitis. Ophthalmology Propionibacterium

6 Stern GA, Engel HM, Driebe WT. Recurrent postoperative endophthalmitis. Cornea 1990; 9: 102-7.

7 Fox G, Joondeph BC, Flynn HW, Pflugfelder SC, Roussel TJ. Delayed onset pseudophakic endophthalmitis. Am $\mathscr{f}$ Ophthalmol 1991; 111: 163-73.

8 Haimann $M H$, Weiss $H$, Miller JA. Delayed onset pseudophakic endophthalmitis. Am f Ophthalmol 1991; 111 : 656 .

9 Whitcup SM, Belfort R, de Sweet MD, Palestine AG, Nussenblatt RB, Chen CC. Immunohistochemistry of the inflammatory response in Propionibacterium acnes endophthalmitis. Arch Ophthalmol 1991; 109: 978-9.

10 Yang CM, Cousens SW. Fate of the fellow eye after Propionibacterium acnes endophthalmitis. Am $\mathcal{F}$ Ophthalmol 1991; bacterium acnes

11 Allen HF, Mangiaricine AB. Bacterial endophthalmitis after cataract extraction. Arch Ophthalmol 1964; 72: 454-62.

12 Gerding DN, Poley B, Hall WH, Le Win DP, Clark MD. Treatment of pseudomonas endophthalmitis associated with prosthetic intraocular lens implantation. Am $\mathcal{F}$ Ophthalmo 1979; 88: 902-8.

13 Petit TH, Olson RJ, Foos RY, Martin RJ. Fungal endophthalmitis following intraocular lens implantation: a surgical epidemic. Arch Ophthalmol 1980; 98: 1025-39.

14 Cummins CS, Johnson JL. Corynebacterium parvum: a synonym for Propionibacterium acnes? F Gen Microbiol 1974; 80: $433-42$.

15 Brook I. Pathogenicity of Propionibacterium acnes in mixed infections with facultative bacteria. F Med Microbiol 1991; infections with $249-52$.

16 Webster GF, Leyden JJ, Musson RA, Douglas SD. Susceptibility of Propionibacterium acnes to killing and degradation by human neutrophils and monocytes in vitro. Infection and Immunity 1985; 49: 116-21.

17 Smith RE. Inflammation after cataract surgery. Am $f$ Ophthalmol 1986; 102: 788-90.

18 Vafidis GC, Marsh RJ, Stacey AR. Bacterial contamination of intraocular lens surgery. Br f Ophthalmol 1984; 68: 520-3.

19 Griffiths PG, Elliot TSJ, McTaggart L. Adherence of Staphylococcus epidermidis to intraocular lenses. $\mathrm{Br} \mathcal{F}$ Staphylococcus epidermidis
Ophthalmol 1989; 73: 402-6.
20 Semel J, Nobe J, Bowe B, Finegold S, Smith RE. Propionibacterium acnes isolated from explanted intraocular lenses in pseudophakic bullous keratopathy. Cornea 1989; 8: 259-62.

21 Cusumano A, Busin M, Spitznas M. Is chronic intraocular inflammation after lens implantation of bacterial origin? Ophthalmology 1991; 98: 1703-10.

22 Jansen B, Hartmann C, Schumacher-Perdreau F, Peters G. Late onset endophthalmitis associated with intraocular lens: a case of molecularly proved $S$ epidermidis aetiology. $\mathrm{Br} \mathscr{F}$ a case of molecularly proved
Ophthalmol 1991; 75: 440-1.

23 Menikoff JA, Speaker MG, Marmor M, Raskin EM. A case control study of risk factors for postoperative control study of risk factors for postope

24 Stenevi U, Apple D. Propionibacterium acnes endophthalmitis. Eur F Implant Refractive Surg 1992; 4: 193-4.

25 Vafidis G. Propionibacterium acnes endophthalmitis. $\mathrm{Br} \mathcal{F}$ Ophthalmol 1991; 75: 706

26 Weber DJ, Hoffman KL, Thoft RA, Baker AS Endophthalmitis following intraocular lens implantation: report of 30 cases and review of the literature. Rev Infect Dis 1986; 8: $12-20$.

27 O'Day DM, Jones DB, Patrinely J, Elliot JH. Staphylococcus epidermidis endophthalmitis. Visual outcome following noninvasive therapy. Ophthalmology 1982; 89: 354-60.

28 Shrader SK, Band JD, Lauter CB, Murphy P. The clinical spectrum of endophthalmitis: incidence predisposing factrum of end features influencing outcome. F Infect Dis 1990; 162: $115-20$.

29 Adenis JP. Endophthalmitis: new trends. Chibret Int $\mathcal{f}$ Ophthalmol 1991; 8: 67-70.

30 Meisler DM, Zakov ZN, Bruner WE, Hall GS, McMahon JT Zachary AA, et al. Endophthalmitis associated with sequestered intraocular Propionibacterium acnes. Am Ophthalmol 1987; 104: 428-9.

31 Garner A. Complications of prosthetic intraocular lens implantation: a histopathologic study. $\mathrm{Br} \mathcal{F}$ Ophthalmol 1989; 73: 940-5.

32 Friberg TR, Kuzma PM. Propionibacterium acnes endophthalmitis two years after cataract extraction. $A m \mathcal{F}$ Ondophthalmitis two years after

33 Chien AM, Raber IM, Fischer DH, Eagle RC, Nardoff MA. Propionibacterium acnes endophthalmitis after intracapsular cataract extraction. Ophthalmology 1992; 99: 487-90.

34 Rothman RJ, Friberg TJ, Kavenchak LM, Kowalski RP. Letter] Retina 1990; 10: 319-21.

35 Joondeph BC, Flynn HW, Miller D, Joondeph HC. A new culture method for infectious endophthalmitis. Arch Ophthalmol 1989; 107: 1334-7.

36 Wang WLL, Everett ED, Johnson M, Dean E. Susceptibility of Propionibacterium acnes to seventeen antibiotics. Antimicrob Agents Chemotherapy 1977; 11: 171-3.

37 Davis JL, Koidou-Tsiligianni A, Pflugfelder SC, Miller D, Flynn HW, Forster RK. Coagulase negative staphylococcal Flynn HW, Forster RK. Coagulase negative staphylocc

38 Mao LK, Flyn HW, Miller D, Pflugfelder SC Endophthalmitis caused by streptococcal species. Arch Ophthalmol 1992; 110: 798-801.

39 Stern GA, Engel HM, Driebe WT. The treatment of postoperative endophthalmitis: results of differing approaches to treatment. Ophthalmology 1989; 96: 62-7.

40 Oum BS, D'Amico DJ, .Wong KW. Intravitreal antibiotic therapy with vancomycin and aminoglycoside. Arch Ophthalmol 1989; 107: 1055-60.

41 Fisch A, Salvanet A, Prazuck T, Forestier F, Gerbaud L, Coscas G, et al. Epidemiology of infective endophthalmitis in France. Lancet 1991; 338: 1373-6.

42 Javitt JC, Vitale S, Conner JK, Street DA, Krakauer H, McBean AM, et al. Endophthalmitis rates for more than McBean AM, et al. Endophthalmitis rates for more than 1085-9.

43 Sherwood DR, Rich WJ, Jacobs JS, Hart RJ, Fairchild YL. Bacterial contamination of intraocular and extraocular fluids during extracapsular cataract extraction. Eye 1989; 3: 308-12.

44 Walker J, Dangel ME, Makley TA, Opremcak EM. Postoperative Propionibacterium granulosum endophthalmitis. Arch Ophthalmol 1990; 108: 1073-4.

45 Manners RM, Canning CR. Posterior lens capsule abscess do to Propionibacterium acnes and Staphylococcus epidermidis following extracapsular cataract extraction. Brf Ophthalmol following extracaps 